\title{
Prevention of fever and Gram negative infection after open heart surgery by antiendotoxin
}

\author{
R FREEMAN, FK GOULD \\ From the Department of Microbiology, Freeman Hospital, Newcastle upon Tyne
}

ABSTRACT Naturally occurring preoperative antibody to enteric Gram negative bacilli (Escherichia coli agglutinins or antiendotoxin, or both) in 30 patients who had had open heart surgery was associated with a significantly lower incidence of early postoperative fever and postoperative Gram negative infection than occurred in 56 patients without preoperative antibodies. The protective effect was shown to be associated with antiendotoxin rather than antibody to the somatic antigen of the bacteria. Active or passive immunisation of patients having open heart surgery against endotoxin is likely to decrease significantly the morbidity after cardiopulmonary bypass.

We recently reported that $70-80 \%$ of patients undergoing open heart surgery developed antibodies to enteric Gram negative bacilli in early convalescence, in contrast to patients undergoing closed heart precedures. ${ }^{\prime}$ Although the explanation for this phenomenon was not immediately apparent, it was suggested that it was a serological response to endotoxin and other products of enteric Gram negative bacilli released by cardiopulmonary bypass. Since $20 \%$ of these patients had detectable antibodies before operation we have compared the postoperative progress of those patients known to be seropositive before operation with those known to be seronegative. By this means we hoped to link positive serological findings to significant postoperative clinical events.

\section{Methods}

Serological results on paired sera (preoperative and 10-14 days after operation) were available on the 64 patients who underwent open heart surgery already reported. In that series titres of agglutinating antibodies to seven common serotypes of Escherichia coli were determined in paired sera from all 64 patients, but titres of precipitating antibody titre to endotoxin were determined in only 22 cases. For the present study antiendotoxin tests were

Address for reprint requests: Dr $\mathbf{R}$ Freeman, Department of Microbiology, Freeman Hospital, Newcastle upon Tyne NE7 7DN.

Accepted 18 April 1985 performed on the remainder. Additionally, both types of antibody were tested for in paired sera taken from a further 22 consecutive patients who had open heart surgery. Testing for $E$ coli agglutinins and antiendotoxin was as described previously. ${ }^{1}$ The medical records of all 86 patients were obtained for study and particular note was made of the following details: (1) age and sex of the patient and nature of operation; (2) incidence and duration of postoperative fever-defined as a temperature of $>38^{\circ} \mathrm{C}$ and, as in a previous study, ${ }^{2}$ classified as either $(a)$ early fever (occurring within 24 hours of operation) or $(b)$ late fever (occurring 48 or more hours after operation); (3) incidence and nature of any documented postoperative infection; (4) mortality.

\section{Results}

Of the total 86 patients, $46(52 \%)$ developed fever within 24 hours of operation. The mean time from operation to onset of the early fever was 8.3 hours and the mean duration was 9.0 hours. In no case did early fever fail to remit within 24 hours of operation. Late fever occurred in 41 patients (48\%), the mean time between operation and onset being 2.3 days and the mean duration being 4.2 days.

Overall 17 patients (20\%) had proved postoperative infection. Of these, four were septicaemias, the organisms being Escherichia coli (two cases), Proteus mirabilis, and Klebsiella edwardsii. Urinary tract infection occurred in seven patients, the organisms being $E$ coli (three cases), Proteus mirabilis (three cases), and Klebsiella aerogenes. One of the 
patients with $E$ coli septicaemia had the same organism isolated from the urine. Wound infection was documented in four patients, Staphylococcus aureus being isolated in two and $E$ coli in the others. Finally, appreciable chest infection (purulent sputum, fever, and radiological confirmation) was found in two patients, Haemophilus infuenzae being isolated in both instances. Eight patients died while in hospital for the open heart procedure. None of these deaths was attributable to infection.

The table shows the observed associations between these clinical events and preoperative serological findings for the patients concerned, separating those with $E$ coli antibody, with antiendotoxin, and with either of these. Early postoperative fever, all infection, and infection due to enteric Gram negative bacilli were all significantly less common in the patients possessing either antibody before operation. Similar correlations are seen for patients possessing preoperative antiendotoxin regardless of whether they also possessed preoperative $E$ coli agglutinins, but not vice versa. Analysis of the data for the 30 patients with preoperative antibody of either specificity and comparison with the remaining 56 patients failed to show any significant differences in terms of age (antibody positive group: mean 52.2 years; antibody negative group: mean 52.7 years), sex (male:female ratios $21: 9$ and $41: 15$ ), or type of operation (valve replacement: bypass graft ratios $11: 19$ and $27: 29$ ). No significant differences were found in the amounts of blood transfused.

\section{Discussion}

These results show that patients with preoperative antibody to enteric Gram negative bacilli are significantly protected against postoperative infection when undergoing open heart surgery. They are also significantly less likely to develop the common self limiting fever seen in the first 24 hours after operation..$^{2}$ The protective effect of the preoperative antibody can be significantly correlated with an antiendotoxin component, whereas when analysis is limited to those with agglutinating antibody to $E$ coli the protective effect falls short of significance, although a trend suggesting protection is still apparent.

Significant amelioration of the effects of serious Gram negative infection, particularly disseminated intravascular coagulation and shock, by the administration of serum containing antibody to endotoxin has been demonstrated by others. ${ }^{34}$ Furthermore, such beneficial effects have been shown to be due to antiendotoxin rather than antibody to surface components of enteric Gram negative bacilli. ${ }^{5}$ This latter finding accords with the lesser protection afforded by $E$ coli agglutinins in our study since this antibody is directed against the somatic $\mathrm{O}$ antigen and not endotoxin. Some previous studies have discounted a protective effect of "natural" antibody to enteric Gram negative bacilli'; they were concerned, however, with "O" antibodies and not antiendotoxin.

The protective effect of preoperative antibodies against the early fever seen so commonly after cardiopulmonary bypass strongly suggests that enteric Gram negative bacilli, endotoxin, or some other component of these bacteria has a role in the genesis of this complication of open heart surgery. The exact aetiology of this condition, however, will require further study. Recent work has shown that preoperative provision of antibodies to enteric Gram negative bacilli, particularly antiendotoxin, to patients about to undergo surgery will confer significant protection against Gram negative infection, whether the protective antibody is provided by prior immunisation ${ }^{7}$ or by passive immunity. ${ }^{8}$ We believe that similar techniques could be used for patients having open heart surgery with great benefit. Moreover, our findings identify patients hav-

Observed associations between postoperative clinical events and the preoperative antibody findings in 86 patients undergoing open heart surgery

\begin{tabular}{|c|c|c|c|c|c|c|}
\hline \multirow[t]{3}{*}{ Clinical event } & \multicolumn{6}{|c|}{ Preoperative antibody } \\
\hline & \multicolumn{2}{|c|}{ E coli agglutinins } & \multicolumn{2}{|c|}{ Antiendotoxin } & \multicolumn{2}{|l|}{ Either } \\
\hline & $\begin{array}{l}\text { Present } \\
(n=17)\end{array}$ & $\begin{array}{l}\text { Absent } \\
(n=69)\end{array}$ & $\begin{array}{l}\text { Present } \\
(n=21)\end{array}$ & $\begin{array}{l}\text { Absent } \\
(n=65)\end{array}$ & $\begin{array}{l}\text { Present } \\
(n=30)\end{array}$ & $\begin{array}{l}\text { Absent } \\
(n=56)\end{array}$ \\
\hline $\begin{array}{l}\text { Early fever } \dagger \\
\text { Late fever } \dagger \\
\text { Any infection } \\
\text { Gram positive infection } \\
\text { Gram negative infection } \\
\text { Septicaemia (all Gram negative) } \\
\text { Death during this admission }\end{array}$ & $\begin{array}{r}5 \\
10 \\
1 \\
0 \\
1 \\
0 \\
0\end{array}$ & $\begin{array}{r}40 \\
31 \\
16 \\
2 \\
14 \\
4 \\
8\end{array}$ & $\begin{array}{r}6 \\
10 \\
0 \\
0 \\
0 \\
0 \\
2\end{array}$ & $\begin{array}{l}39^{*} \\
31 \\
17^{*} \\
2 \\
15^{*} \\
4 \\
6\end{array}$ & $\begin{array}{r}9 \\
18 \\
1 \\
0 \\
1 \\
0 \\
2\end{array}$ & $\begin{array}{l}36^{* *} \\
23 \\
16^{* *} \\
2 \\
14^{*} \\
4 \\
6\end{array}$ \\
\hline
\end{tabular}

${ }^{*} \mathrm{p}<0.05>0.01 ;{ }^{* *} \mathrm{p}<0.01$. For all comparisons between groups the $\chi^{2}$ test was used with Yates's correction factor.

+See under "Methods." 
ing open heart surgery as a group with a high incidence of rises in antibody to Gram negative antigens and thus worthy of further study.

\section{References}

1 Freeman R, Gould FK. Rises in antibody to enteric Gram negative bacilli after open heart surgery: a possible mechanism for postoperative pyrexia. Thorax 1985; 40: 538-41.

2 Dominguez de Villota, E Barat G, Astorqui F, Damaso $D$, Avello F. Pyrexia following open-heart surgery. Anaesthesia 1974;29:529-36.

3 Ziegler EJ, McCutchan A, Fierer J, et al. Treatment of Gram negative bacteraemia and shock with human antiserum to a mutant Escherichia coli. $N$ Eng J Med 1982;107:1225-30.
4 Braude A, Douglas H, Davis CE. Treatment and prevention of intravascular coagulation with antiserum to endotoxin. J Infect Dis 1973;128, suppl:S157-64.

5 McCabe WR, Greely A, DiGenio T, Johns MA. Humoral immunity to type-specific and cross-reactive antigens of Gram negative bacilli. J Infect Dis 1973;128, suppl:S284-9.

6 Vosti KL, Monto AS, Rantz LA. Host-parasite interaction in patients with infections due to Escherichia coli. II-Serologic response of the host. J Lab Clin Med 1965;66:613-26.

7 Braude A, Ziegler EJ, Douglas H, McCutchan JA. Antibody to cell wall glycolipid of Gram negative bacteria-induction of immunity to bacteremia and endotoxemia. J Infect Dis 1977;136, suppl:S167-73.

8 Lachman E, Pitsoe SB, Gaffin SL. Antilipopolysaccharide immunotherapy in management of septic shock of obstetric and gynaecological origin. Lancet 1984;i:981-3. 